\title{
Study on the Pigments of Chinese Ancient Architectural Colored Drawing in the Altar of Agriculture (Beijing, China) by portable Raman Spectroscopy and Hand-held X-ray Fluorescence Spectrometry
}

\section{Yan Li}

University of Science and Technology Beijing

Fengping Wang ( $\square$ fpwang@ustb.edu.cn )

University of Science and Technology Beijing

Junjie Ma

University of Science and Technology Beijing

Kang He

University of Science and Technology Bejing

Min Zhang

Bejing Ancient Architecture Museum

Research article

Keywords: the architectural colored drawings, in-situ analysis, portable Raman spectroscopy, the Altar of Agriculture

Posted Date: August 7th, 2020

DOI: https://doi.org/10.21203/rs.3.rs-54247/v1

License: (c) (i) This work is licensed under a Creative Commons Attribution 4.0 International License.

Read Full License 


\section{Abstract}

As a precious treasure in the history of Chinese architecture, Chinese ancient architectural colored drawing is an important cultural heritage. Knowing exactly the pigment composition in the ancient architectural colored drawing is of great significance to understand and protection of the cultural relic. The in-situ measurement was carried out on the pigments used in the ancient architecture colored drawing in the Altar of Agriculture (Beijing, China) for the first time by Portable Raman spectroscopy and hand-held x-ray fluorescence spectroscopy. The components of the typical pigments, such as red, green, blue, white and black in the colored drawings were studied by spectral analysis and the relationship between the color and material composition of the pigments, including red lead $\left(\mathrm{Pb}_{3} \mathrm{O}_{4}\right)$, massicot $(\mathrm{PbO})$, carbon black (amorphous $\mathrm{C}$ ), lead white $\left(\mathrm{PbCO}_{3} \cdot \mathrm{Pb}(\mathrm{OH})_{2}\right)$, indigo $\left(\mathrm{C}_{16} \mathrm{H}_{10} \mathrm{~N}_{2} \mathrm{O}_{2}\right)$, and atacamite $\left(\mathrm{Cu}_{2}(\mathrm{OH})_{3} \mathrm{Cl}\right)$ were established as well. According to the application history of the pigments and the records of the Altar of Agriculture, these colored drawings could be dated to the Qianlong period. Information about these pigments can help preserve and restore architectural drawings in the Altar of Agriculture (Beijing, China) as well as the architectural colored drawings in other Chinese ancient architecture.

\section{Introduction}

Chinese traditional ancient architectural drawings are a very valuable part of Chinese ancient architectural heritage and one of the highlights of the world's architectural art history. Chinese ancient architectural drawings not only demonstrate China's unique art deco aesthetic but also reflect the Chinese people's art, culture, and ideological concept. Furthermore, these Chinese architectural drawings can present the historical application of pigments, the painting skills, and the age messages of the ancient architectures. The architectural colored drawings behave as the decoration and hierarchy for Chinese ancient architecture. Meanwhile, they play the protection role for the wooden framework from the destruction of the water and insects.

The Altar of Agriculture (Beijing) is a typical and famous ancient Chinese architecture group. It has been listed as national key cultural relics in 2001. The Altar of Agriculture was the place where emperors of Ming and Qing dynasties held the ceremony of offering sacrifices to Xiannong and other gods, and the ceremony of planting by emperors themselves. It had been originally constructed in the eighteenth year of the Yongle period of the Ming Dynasty (A.D. 1420) and renovated in the eighteenth year of the Qianlong period of the Qing Dynasty (A.D. 1753). Each part of these architectures in the Altar of Agriculture is decorated with exquisite Chinese traditional drawings. Most architectural drawings in the Altar of Agriculture belong to tangent circle pattern. Tangent circle pattern was most widely used in ancient architecture, such as Yamun and Temples of the Qing Dynasty. However, due to the natural and human factors especially the wars in 1900, most of the architectural drawings in the Altar of Agriculture had been damaged seriously, such as cracking, flaking, fading, graffito, and smudging (Fig. S1a and S1b), which makes the elegant drawings lose their original appearance and primary beauty. Although most of them have been redrawn from 1998 to 2000, as shown in Fig. 1a and 1b. Abundant modern pigments were 
used since almost no knowledge of the drawing pigments, resulting in the loss of the original ancient architectural drawing. Till now, no record of the original pigments of the ancient architectural drawing in the Altar of Agriculture has been found. Therefore, the study and identification of the architectural colored drawings are of great significance and imperative for the protection and restoration process.

Recently, by sampling method, significant research on identifying pigments used in the architectural drawings of the ancient architectures has been carried out. Through SEM-EDX, XRD, and PY-GC-MS, Rocco Mazzeo et al. studied the samples collected from the construction drawings of Drum Tower in Xi'an, and the results showed that the pigments were both original and a later application from the XVIII century [1]. Liqin Wang et al. analyzed the sampled drawings in the Renshou Hall and presented the components of pigments and binders used in the drawings by using XRD, XRF, and EA [2]. Junwei He studied the blue pigments by sampling the paintings of Changshu Caiyitang and showed that the blue pigments are azurite and indigo [3]. However, all the above studies were conducted by sampling rather than in situ measurement. In fact, the study by sampling is often prohibited due to the limitation of cultural heritage protection. Especially the Altar of Agriculture, the precious original architectural drawings have remained few. Each of the remaining original murals is a rarity and bears the historical and cultural information in that age. Therefore, non-destructive and in-situ methods are necessary. Raman spectroscopy is just the right approach by which the material components can be non-invasively identified with high sensitivity, reliability, and spatial resolution.

Currently, Raman spectroscopy is widely used in the field of cultural heritage because conservators and art historians enable to precise identify of artworks based on the Raman spectrum. The fingerprint recognition function of Raman spectroscopy allows the identification of the types of artistic material, such as inorganic and organic pigments [4, 5], varnishes [6], and binding media [7], which can provide information about the attribution of artworks and insight into the artists' techniques. The portable Raman instrument is convenient to perform an on-site analysis of the artifacts without damaging the work of art. And the hand-held ED-XRF is employed as a supplementary method to help identify the pigments.

In this study, we focus on the study and identification of the original pigments of the ancient architectural drawings in the Altar of Agriculture (Beijing) by in-situ Raman and ED-XRF spectra. Further, we explore the historical and cultural information of the architectural drawings in the Altar of Agriculture.

\section{Materials And Methods}

\section{Ancient architectural colored drawings}

In this study, Sacrificial Storehouse is chosen as the objective. Sacrificial Storehouse was the place to store the utensils for sacrifice during the Ming and Qing Dynasty. Now, the Sacrificial Storehouse is used to exhibit the agricultural history and traditional farm tools of China. It is an important building for visitors to learn about the agricultural history of China. The drawing on the lowest wooden beam is selected as the measurement objective because these architectural drawings are well-preserved, as 
shown in Fig. 2. The five-color regions on the architectural drawing were measured in-situ by portable Raman instrument and hand-held $x$-ray fluorescence spectrometer, including red, blue, black, green, and white. All the measured points are marked in Fig. 2 and divided into six groups by color. Namely, P1, P7, P10, and P13 present red color; P2 and P4 present green color; P3 and P14 present black color; P6 and P9 present white color; $\mathrm{P} 5, \mathrm{P} 8$, and $\mathrm{P} 11$ present blue color; $\mathrm{P} 12$ is the ground layer. The measurements have been completed in the autumn of 2018 (18-30 October)

\section{Instruments}

The Raman spectra of the colored areas were recorded using a portable Raman spectrometer (EmVision LLC., America) equipped with a thermoelectrically cooled CCD detector $\left(-50^{\circ} \mathrm{C}\right)$. The excitation wavelength was provided by a diode laser emitting at $785.0 \mathrm{~nm}$. Laser power was adjusted up to a maximum of ca. $30 \mathrm{~mW}$ at the sample to avoid all possible damage. This laser power was rarely used and only on white surfaces, while for other colors, the laser power was reduced to few milliwatts. All spectra were acquired with a spectral resolution of $4 \mathrm{~cm}^{-1}$ in the spectral range of $100-2000 \mathrm{~cm}^{-1}$. The probe uses seven low hydroxyl $(\mathrm{OH})$ content 300 -micron core, $0.22 \mathrm{NA}$ collection fibers. A donut-shaped long-pass filter that rejects the laser light and passes the Raman light from the sample is positioned in front of these seven fibers. The work distance of the probe is ca. $5 \mathrm{~mm}$. This technology improves the collection efficiency and is very beneficial in applications requiring frequent probe removal. The spectra were typically recorded in situ collecting one accumulation each of $2 \mathrm{~s}$ duration. The instrument was calibrated by using an acetaminophen tablet before each set of measurements.

ED-XRF spectra of the architectural drawing are recorded by a Thermo Scientific Niton XL3t with a Soil Mode calibration for a total time of 60 seconds ( $30 \mathrm{~s}$ Main range and $30 \mathrm{~s}$ for low range). A Silicon PIN detector is used to collect the fluorescence radiation from the sample. The instrument with a Silicon PIN detector is sensitive to $X$-rays that are higher on the periodic table than sulfur (S). The resolution of the Silicon PIN detector is better than $175 \mathrm{eV}$. Analytical processes are performed by its software.

\section{The methodology of in-situ measurement}

The drawing is located at a height of about $3.2 \mathrm{~m}$ above the ground. Some instruments were adopted to help the probe head reach the selected areas. The detailed instruments are presented in Fig. 2a. A desk with a height of ca. $1.2 \mathrm{~m}$ is placed on the floor. Then, a wooden bench with a height of ca. $0.6 \mathrm{~m}$ is put on the desk. On the bench, a tripod is placed to help the probe head reach the measurement points. A micro-displacement which can adjust the displacement distance from 0.01 to $10.00 \mathrm{~mm}$ is fastened on the holder of the tripod. The probe head is mounted on the micro-displacement platform. The focus of the probe head is precisely controlled by adjusting the micro-displacement platform. Another desk with a height of ca. $1.5 \mathrm{~m}$ is placed beside the desk for the spectrometer, the laser, and the computer.

Through this set of equipment, the probe head can successfully reach and focus on the selected positions. 


\section{Results And Discussion}

The color of black, red, white, green, and blue of the architectural drawing are measured by Raman and ED-XRF spectroscopy. The spectra of the pigments are successfully obtained. The detailed results are shown in the subsequent sections.

\section{Black pigment}

In the black areas, all the measured points give alike Raman signals. Two typical spectra collected from P14 and P3 are shown in Fig. 4a and 4b. There are two broad Raman bands at around 1333 and $1588 \mathrm{~cm}^{-1}$. These two bands are assigned to carbon black $[8,9]$. The XRF spectra of the black area presented in Fig. $4 \mathrm{~d}$ indicates that $\mathrm{Ca}$, $\mathrm{Fe}$ and $\mathrm{Pb}$ elements are observed which is in accordance with the elements of the ground layer (Fig. 4c). The component of the black pigments should contain light elements (such as $\mathrm{C}$ element) which are beyond the detection limit of the instruments. According to the results of Raman and ED-XRF analysis, it is surely that carbon black was used as a black pigment in the architectural drawings. The Carbon black used usually comes from the incomplete combustion products of organic material such as plants, oil, and bones. In ancient China, carbon black is the main black pigment in the artworks. It has been found that carbon black was used as black pigments in the pottery figurines of the Han Dynasty, the murals of Mogao Grottoes, the architectural drawings in Forbidden City $[1,10]$. Even now, it is also used as a black pigment in calligraphy, advertising, and drawings. The extensive and long-term application of carbon black is mainly because of its stable physical and chemical properties, and a rather low cost. Therefore, it is thought carbon black is used as the black pigment in the architectural drawings.

\section{White pigment}

Figure 5 The Raman spectra and ED-XRF of the white area a) P6, b) P9, c) ED-XRF of ground layer, d) EDXRF of the white layer

The typical spectra obtained from the white area is shown in Fig. $5 \mathrm{a}$ and $5 \mathrm{~b}$. They both give only one Raman band at $1049 \mathrm{~cm}^{-1}$ which is assignable to $\mathrm{v}\left(\mathrm{CO}_{3}{ }^{2-}\right)$ modes in lead white $\left(\mathrm{PbCO}_{3}\right)$ [11-13]. It is deduced that white lead is used as the white pigment. For further confirmation, the ED-XRF spectra of the corresponding white area and the ground layer have been collected and are presented in Fig. 5d. Ca, Fe and $\mathrm{Pb}$ elements are found. By comparing with the spectra of the ground layer (Fig. 5c), it can be seen that the amount of $\mathrm{Pb}$ element in the white area is much higher than the amount of $\mathrm{Pb}$ element in the ground layer. It means that the components of the white pigments contain $\mathrm{Pb}$ element. The white pigment which contains the $\mathrm{Pb}$ element is lead white. These results are in keeping with the result of the Raman analysis. Meanwhile, $\mathrm{S}$ and $\mathrm{Ca}$ element is also observed at the white color region from ED-XRF spectra. and the amount of $\mathrm{Ca}$ element is higher than the amount in the ground layer, so it is deduced that there is calcium sulfate in the white area. However, the Raman spectra in the white color region haven't given the 
corresponding bands of calcium sulfate, it is evident that there is a very small amount of calcium sulfate in the white area. White lead as a white pigment is an ancient pigment which was widely used in murals and architectural drawings, such as the 17 th -century panel painting, medieval manuscripts $[14,15]$.

\section{Blue pigments}

As presented in Fig. 6, spectra collected from blue areas (P7, P10, and P13) can be divided into two series. In Fig. $6 a$, the Raman bands at 246, 540, 594, 670, $1574 \mathrm{~cm}^{-1}$ are found and can be ascribed to indigo $\left(\mathrm{C}_{16} \mathrm{H}_{10} \mathrm{~N}_{2} \mathrm{O}_{2}\right)$ which is derived from the plant Indigofera tinctoria and related species [16, 17]. In Fig. $6 \mathrm{~b}$ and $6 \mathrm{c}$, only one peak at $1574 \mathrm{~cm}^{-1}$ are presented and can be also attributed to indigo. The XRF spectra of the blue area presented in Fig. 5e indicates that no new elements are found, except for $\mathrm{Ca}, \mathrm{Fe}$, and $\mathrm{Pb}$ elements which are also found in the ground layer. It demonstrates that the pigment used in the blue areas is plantal pigment which contains light elements (such as $\mathrm{C}, \mathrm{H}, \mathrm{O}$, and $\mathrm{N}$ elements) beyond the detection limits of the instruments. Combining with the results of Raman analysis, it is surely that indigo is used as a blue pigment in the architectural drawings. Indigo, as an ancient pigment, found in many arts, such as Mediaeval Latin manuscripts, the Maya wall paintings. In China, indigo was usually used to dye the clothes, like the Western Han silk found in Changsha Mawangdui.[18] Even now, it is still be used to dye the jeans. Indigo was also found in some architectural drawings. In Forbidden City, Yong Lei has found that indigo was used as the primary blue pigment in the architectural drawings of Jianfu Palace which was constructed at A.D. 1742 and restored in A.D. 1802 [19]. After restoration, it is found that smalt was adopted to replace indigo as a blue pigment in the architectural drawings. Therefore, it is deduced that indigo was often used as blue pigments in the architectural drawings of royal architecture before smalt was widely used in China after A.D. 1802. The Altar of Agriculture, also as a royal architecture, was very likely to adopt indigo as blue pigment and these architectural drawings were painted at least before A.D. 1802.

\section{Red pigments}

In the red areas, the measurements were carried out in four typical colored areas (P1, P7, P10, P13). The $\mathrm{P} 1$ and P7 present red color while P10 and P13 present red color. The Raman spectra of these four points are presented in Fig. 7. Raman bands at 122, 142, 392, and $549 \mathrm{~cm}^{-1}$ are observed in P1 and P7 (Fig. 7a and $7 \mathrm{~b}$ ). Bands at 122, 392, and 549 are ascribed to red lead [20]. The band at $142 \mathrm{~cm}^{-1}$ belongs to massicot $(\mathrm{PbO})$ which is a yellow pigment [21]. In P10, bands at 142 and $288 \mathrm{~cm}^{-1}$ are ascribed to massicot (Fig. 6c) while bands at 122, 392, and $549 \mathrm{~cm}^{-1}$ are attributed to red lead. The band at $142 \mathrm{~cm}^{-}$

1 is stronger than the band at $122 \mathrm{~cm}^{-1}$. It is thought that the amount of massicot in P10 is higher than in other measured areas (P1 and P7). In P13, Raman bands at 122, 145, 314, 392, and $549 \mathrm{~cm}^{-1}$ are observed (Fig. 4d). Bands at 122, 314, 392, and 549 are attributed to red lead. The bands at $\sim 145 \mathrm{~cm}^{-1}$ can be divided into two weak peaks, as shown in the insert Figure, 142 and $149 \mathrm{~cm}^{-1}$. The band at $149 \mathrm{~cm}^{-1}$ is also attributed to red lead while the band at $142 \mathrm{~cm}^{-1}$ belongs to massicot $(\mathrm{PbO})$. Raman analysis demonstrates that red lead and massicot are the pigments used in the red areas of the architectural drawings. 
From the analysis of XRF spectra in the red areas and the ground layer (Fig. $7 f$ and $7 \mathrm{e}$ ), the relative amount of $\mathrm{Pb}$ element in the red area is much higher than the relative amount in the ground layer. It reveals that the red pigment is lead-based pigments. This result is in keeping with the result of Raman analysis.

Which pigment is the primary pigment in the red areas? Red lead was often found in the architectural drawings, such as the Drum Tower (Xi'an, China) which was built in 1380 A.D. [1], the Jingfu palace, and Yangxin Hall in the Forbidden City $[22,23]$. Red lead, also called minium, its usage was dating back to the fifth century BC in China. It was a widely used pigment in ancient China. For instance, red lead has been found in Mogao Grottos in Dunhuang, Gansu province in China, which is the famous World Heritage Site [12]. Meanwhile, red lead was also used to print the stamps in the later Qing Dynasty [24]. Up to now, massicot hasn't been found in the red areas of ancient Chinese architecture. So, it is thought that massicot is the impurity in the red areas. In the ancient productive process of red lead, the reaction temperature was very difficult to control accurately. When the reaction temperature exceeded $\sim 520^{\circ} \mathrm{C}$, red lead would transform into massicot. In summary, red lead is the red pigment while massicot is the impurity in the red areas.

\section{Green pigment}

As shown in 2, the Raman spectrum on the green area has not been measured successfully due to very strong fluorescence. The ED-XRF spectra of the ground layer and the green area are presented in Fig. 7a and Fig. $\mathrm{7b}$ respectively. Except for the $\mathrm{Ca}, \mathrm{Fe}$, and $\mathrm{Pb}$ elements which are also observed in the ground layer, $\mathrm{Cu}$ and $\mathrm{Cl}$ elements are found. Therefore, it is thought that the green pigments should contain $\mathrm{Cu}$ and $\mathrm{Cl}$ elements. Generally, three typical green pigments contain $\mathrm{Cu}$ elements used in the ancient arts, namely malachite $\left(\mathrm{CuCO}_{3} \cdot \mathrm{Cu}(\mathrm{OH})_{2}\right)$, atacamite $\left(\mathrm{Cu}_{2}(\mathrm{OH})_{3} \mathrm{Cl}\right)$, and green emerald $\left(\mathrm{Cu}\left(\mathrm{C}_{2} \mathrm{H}_{3} \mathrm{O}_{2}\right)_{2} \cdot 3 \mathrm{Cu}\left(\mathrm{AsO}_{2}\right)_{2}\right)$ [25]. According to the elemental composition of these three pigments, only atacamite contains $\mathrm{Cl}$ element. It is deduced that the green pigment used in the architectural drawings is atacamite. Atacamite has been widely used in the wall drawings of Mogao Grottos and the architectural drawings of Dagaoxuan Temple in the Imperial Palace. However, the architectural drawings of the late Qing dynasty had adopted the artificial pigment (emerald green) as the green pigments due to the excellent properties and low cost. Emerald green has been found in the Renshou Hall (restored in A.D. 1850) and the drawings from Jiayu Pass and other northern Chinese ancient architectures [25, 26]. So, it is supposed that emerald has been widely used in China since the 1850s which atacamite wouldn't be used as green pigments. Therefore, according to the find of atacamite, it could be deduced that these architectural drawings in the Sacrificial Storehouse had been painted at least before 1850 which is coincident with the results for the blue pigment.

In summary, with the help of portable Raman spectroscopy and Hand-held ED-XRF, the pigments used in the architectural drawings are successfully identified. The detailed results are listed in Table 1. According to the history of pigments application in architectural drawings with the historical record about the Altar 
of Agriculture, it is much more likely that these architectural drawings were drawn during the renovation in the eighteenth year of the Qianlong period of Qing Dynasty (A.D. 1753).

Table 1

Samples analyzed, their featured Raman bands, chemical names/formula

\begin{tabular}{|lll|}
\hline Colors & Raman bands $\left(\mathbf{c m}^{-1}\right)$ & Chemical names/formula \\
\hline Red & $121,542,388$ & Red lead, $\mathrm{Pb}_{3} \mathrm{O}_{4}$ \\
\cline { 2 - 3 } & 145,285 & Massicot/litharge, $\mathrm{PbO}$ \\
\hline Blue & $247,540,594,670,1308,1460,1573$ & Indigo, $\mathrm{C}_{16} \mathrm{H}_{10} \mathrm{~N}_{2} \mathrm{O}_{2}$ \\
White & 1047 & White lead, $\mathrm{PbCO}_{3} \cdot \mathrm{Pb}(\mathrm{OH})_{2}$ \\
Black & $\sim 1333, \sim 1580$ & Carbon black \\
\hline Green & No & Atacamite, $\left(\mathrm{Cu}_{2}(\mathrm{OH})_{3} \mathrm{Cl}\right)$ \\
\hline
\end{tabular}

\section{Conclusion}

It can be concluded that the portable Raman spectroscopy is a pretty good approach for the in-situ measurement of the pigments in the architectural drawings of the Altar of Agriculture. Analysis of the Raman spectra revealed that the pigments used in the architectural drawings are all mineral and plantal pigments, including red lead, massicot, indigo, lead white, and carbon black. In the red areas, massicot was speculated as the impurity introduced during the productive process of red lead. With the help of ED$\mathrm{XRF}$, the green pigment is estimated as atacamite. According to the usage history of indigo and atacamite in architectural drawings, it could be deduced that these architectural drawings were painted during the renovation in the eighteenth year of the Qianlong period (A.D. 1753). The pigments used in the architectural drawings of Sacrificial Storehouse are identified and recorded for the first time. Furthermore, this study supplies the accurate and reliable information of pigments used in the architectural drawings of the Altar of Agriculture which can help the conservation and restoration of architectural drawings in the Altar of Agriculture.

\section{Abbreviations}

ED-XRF

energy disperse X-ray fluorescence spectroscopy.

\section{Declarations}

\section{Authors' contributions}


F. wang conceptualized the experiment and revised the drafts of the manuscript. YL chose the object of study, interpreted the data, and wrote early drafts of the manuscript. YL and J. Ma performed in-situ measurements including Raman and ED-XRF experiments. KH solved the problems of the equipment and supplied much useful advice. MZ supported the history of the Atar of Agriculture and help choose the appropriate object of study. All authors read and approved the final manuscript.

\section{Author details}

${ }^{1}$ Department of Physics, School of Mathematics and Physics, University of Science and Technology Beijing, Beijing, PR China; ${ }^{2}$ Beijing Ancient Architecture Museum, Beijing, PR China

\section{Acknowledge}

The authors are grateful to the related staff in the Beijing ancient architecture museum who have supplied a lot of help.

\section{Funding}

The National Natural Science Foundation of China (Grant No. 11874084) funded this research work.

\section{Competing interests}

The authors declare that they have no competing interests.

\section{Availability of datasets}

All data supporting the conclusions of this study can be obtained from the corresponding authors upon reasonable request.

\section{References}

1. Mazzeo R, Cam D, Chiavari G, Fabbri D, Ling H, Prati S. Analytical study of traditional decorative materials and techniques used in Ming Dynasty wooden architecture. The case of the Drum Tower in Xi'an, P.R. of China. J Cult Heri. 2004;5(3):273-83.

2. Wang L, Yang L, Zhou W, Yan J, Guo R. Analysis of the techniques and materials of the coloured paintings in the Renshou Hall in the Summer Palace. Anal Methods. 2015;7(12):5334-7.

3. Decai G, Weijun H, Jinping Z, Mingjun W. Research on the conservation techniques of paintings with no ground layer in Changshu Caiyi Tang. Sciences of conservation archaeology. 2004;16(1):29-32. (in Chinese).

4. Marcelino MdR, Muralha VS. Synthetic organic pigments in contemporary Balinese painting: a Raman microscopy study. J Raman Spectrosc. 2012;43(9):1281-92.

5. Schulte F, Brzezinka K-W, Lutzenberger K, Stege H, Panne U. Raman spectroscopy of synthetic organic pigments used in 20th century works of art. J Raman Spectrosc. 2008;39(10):1455-63. 
6. Edwards HGM, Brooke CJ, Tait JKF. Fourier Transform Raman Spectroscopic Study of Pigments from English Mediaeval Wall Paintings. J Raman Spectrosc. 1997;28(2-3):95-8.

7. Vandenabeele P, von Bohlen A, Moens L, Klockenkämper R, Joukes F, Dewispelaere G. Spectroscopic Examination of Two Egyptian Masks: A Combined Method Approach. Anal Lett. 2000;33(15):331532.

8. Lahlil S, Lebon M, Beck L, Rousselière H, Vignaud C, Reiche I, Menu M, Paillet P, Plassard F. The first in situ micro-Raman spectroscopic analysis of prehistoric cave art of Rouffignac St-Cernin, France. J Raman Spectrosc. 2012;43(11):1637-43.

9. Gutman M, Lesar-Kikelj M, Mladenovič A, Čobal-Sedmak V, Križnar A, Kramar S. Raman microspectroscopic analysis of pigments of the Gothic wall painting from the Dominican Monastery in Ptuj (Slovenia). J Raman Spectrosc. 2014;45(11-12):1103-9.

10. Shen AG, Wang XH, Xie W, Shen J, Li HY, Liu ZA, Hu JM. Pigment identification of colored drawings from Wuying Hall of the Imperial Palace by micro-Raman spectroscopy and energy dispersive X-ray spectroscopy. J Raman Spectrosc. 2006;37(1-3):230-4.

11. Nastova I, Grupče O, Minčeva-Šukarova B, Turan S, Yaygingol M, Ozcatal M, Martinovska V, Jakovlevska-Spirovska Z. Micro-Raman spectroscopic analysis of inks and pigments in illuminated medieval old-Slavonic manuscripts. J Raman Spectrosc. 2012;43(11):1729-36.

12. Xiuye JL, Duan T, Li. Analysis of the pigments used in the murals from 223 and 35. Grottoes Dunhuang Research. 1991;3:101. (in Chinese).

13. Cazzanelli E, Platania E, De Santo G, Fasanella A, Castriota M. Micro-spectroscopic Raman investigation on the canvas oil painting 'Rebecca at the well' of Neapolitan anonymous. J Raman Spectrosc. 2012;43(11):1694-8.

14. Investigation of pigments in medieval manuscripts by micro Wehling B, Vandenabeele P, Moens L, Klockenkämper R, Bohlen AV, Hooydonk GV, Reu MD. Investigation of pigments in medieval manuscripts by micro.

15. Raman spectroscopy and. total reflection X-ray fluorescence spectrometry. Microchim Acta. 1999;130(4):253-60.

16. Pięta E, Proniewicz E, Szmelter-Fausek B, Olszewska-Świetlik J, Proniewicz LM. Micro-Raman spectroscopy analysis of the 17th century panel painting 'Servilius Appius' by Isaac van den Blocke. J Raman Spectrosc. 2014;45(11-12):1019-25.

17. Baran A, Fiedler A, Schulz H, Baranska M. In situ Raman and IR spectroscopic analysis of indigo dye. Anal Methods-UK. 2010;2(9):1372-6.

18. Perardi A, Zoppi A, Castellucci E, Micro-Raman spectroscopy for standard and in situ characterisation of painting materials, J. Cult. Herit 1 (Supplement 1) (2000) S269-S272.

19. Zhang X, Wei X, Lei Y, Cheng X, Zhou C. Micro and Nondestructive Analysis of Blue Dyes from Silk Fabrics and Decorative Painting of Historic Building, Spectrosc. Spect Anal. 2010;30(12):3254-7. (in Chinese). 
20. Yong L, Liang Q, Xiaolin C, Hang Y, Shiwei W. The Discovery of Smalt in Jianfu Palace in Forbidden City, Relics and Museology (2009) 4. (in Chinese).

21. Burgio L, Clark RJH. Library of FT Raman Spectra of Pigments, Minerals, Pigment Media and Varnishes, and Supplement to Existing Library of Raman Spectra of Pigments With Visible Excitation, Spectrochim. Acta Part A Mol. Biomol Spectrosc. 2001;57(7):1491-521.

22. Burgio L, Clark RJH, Firth S. Raman Spectroscopy as a Means for the Identification of Plattnerite (Pb02), of Lead Pigments and of Their Degradation Products. Analyst. 2001;126(2):222-7.

23. Song L. A study on color and pigmens composition of the polychrome paintings of Jingfu Palace in the Forbidden city. Master: Beijing University of Technology; 2017. (in Chinese).

24. Li L, Zhang B, Yang H, Zhang Q. The analysis of the colored paintings from the Yangxin Hall in the Forbidden City. Spectrosc Spect Anal. 2018;7:2054-63. (in Chinese).

25. Zhou Wh, Gan Q, Ji Jx, Yao N, Wang Jg, Zhou Z, Qi Xk. J. I. Shi, Non-destructive identification of pigments printed on six Imperial China Engraved Coiling Dragon stamps. J Raman Spectrosc. 2016;47(3):316-20.

26. Liqin W, Jing Y, Xiaolei F, Tao M. Spectral Analysis of Green Pigments of Painting and Colored Drawing in Northern Chinese Ancient Architectures, Spectrosc. Spect Anal. 2010;3(2):453-7. (in Chinese).

27. Cheng X, Xia Y, Ma Y, Lei Y. Three fabricated pigments (Han purple, indigo and emerald green) in ancient Chinese artifacts studied by Raman microscopy, energy-dispersive X-ray spectrometry and polarized light microscopy. J Raman Spectrosc. 2007;38(10):1274-9.

\section{Figures}
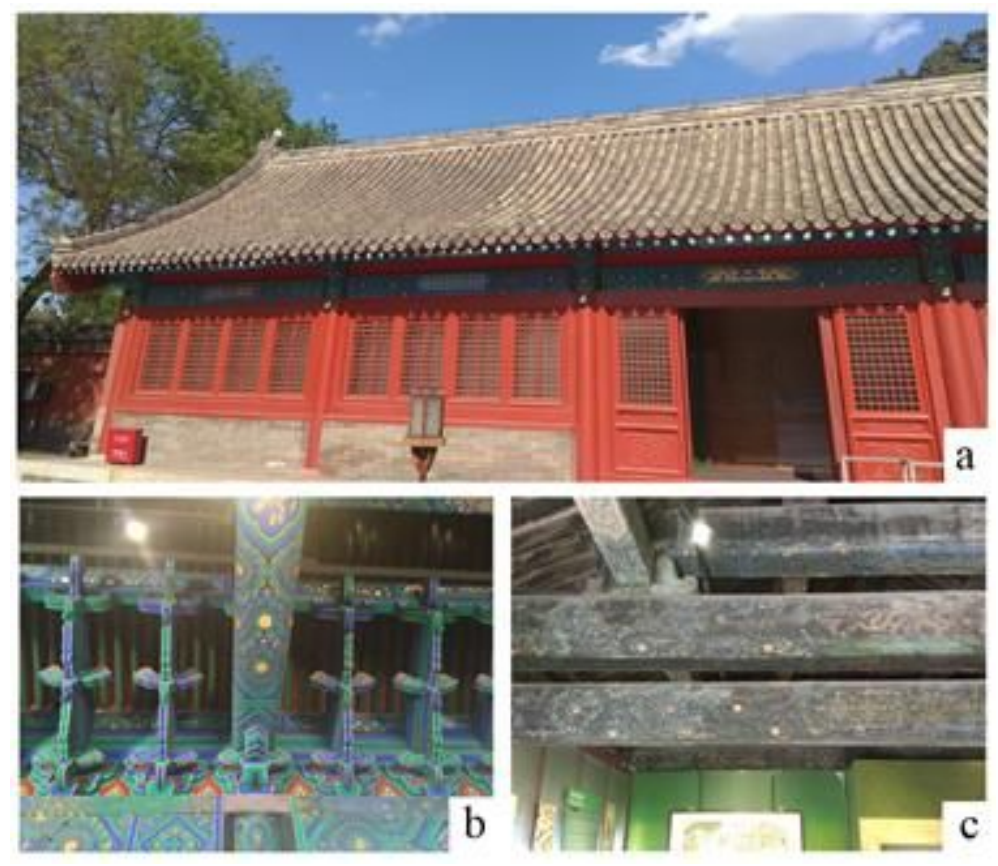

Figure 1 
The photos of the architectural drawings in Altar of Temple; a) the overview of the Sacrificial Storehouse, b) the architectural drawings after restoration, c) the original architectural drawings

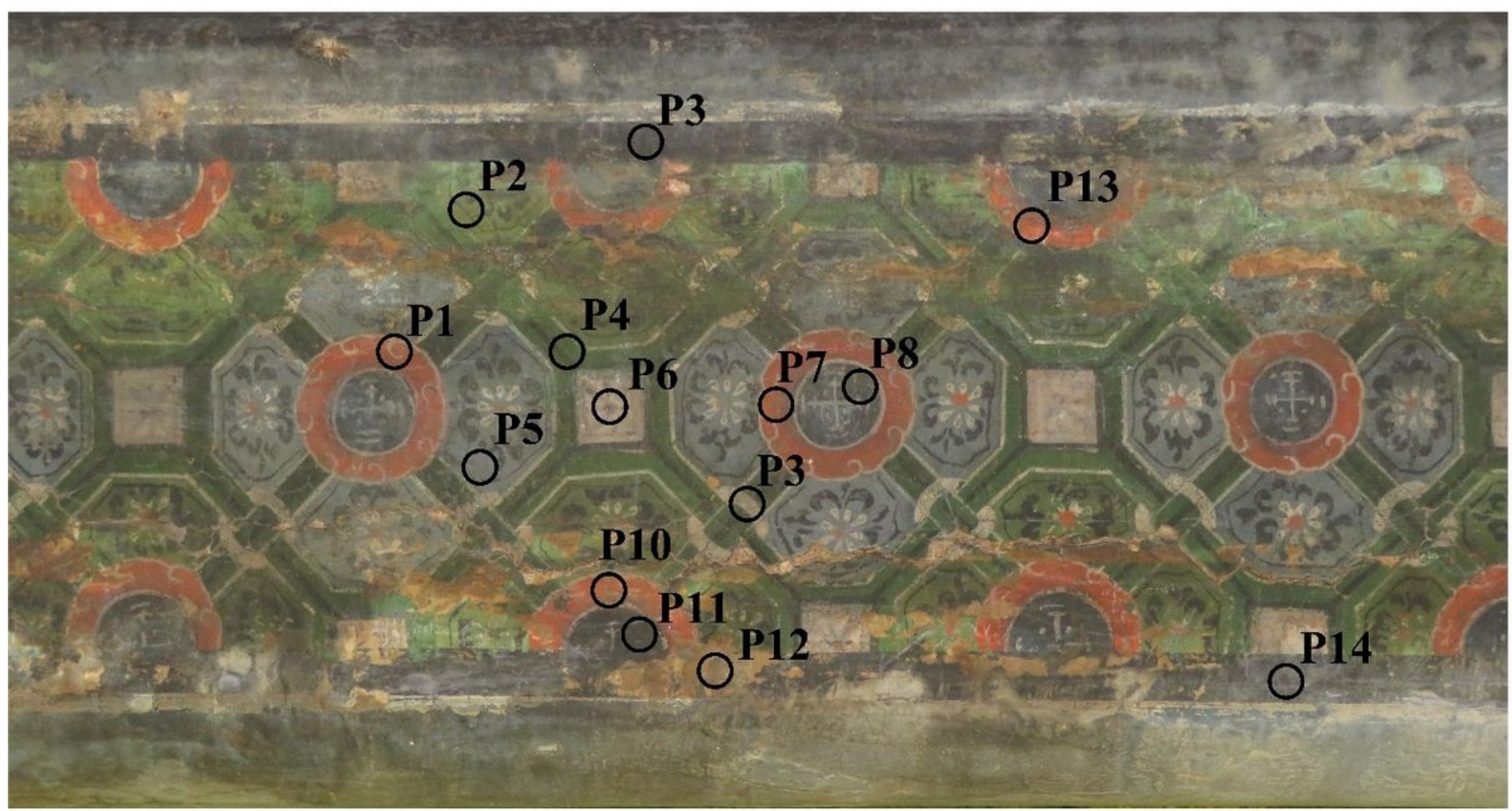

Figure 2

The photos of the architectural drawing and measure points on the wooden beam in Sacrificial Storehouse; red area, P1, P7, P10, P13; green area, P2, P4; black area, P3, P14; white area, P6, P9; blue area, P5, P8, P11; ground layer, P12 


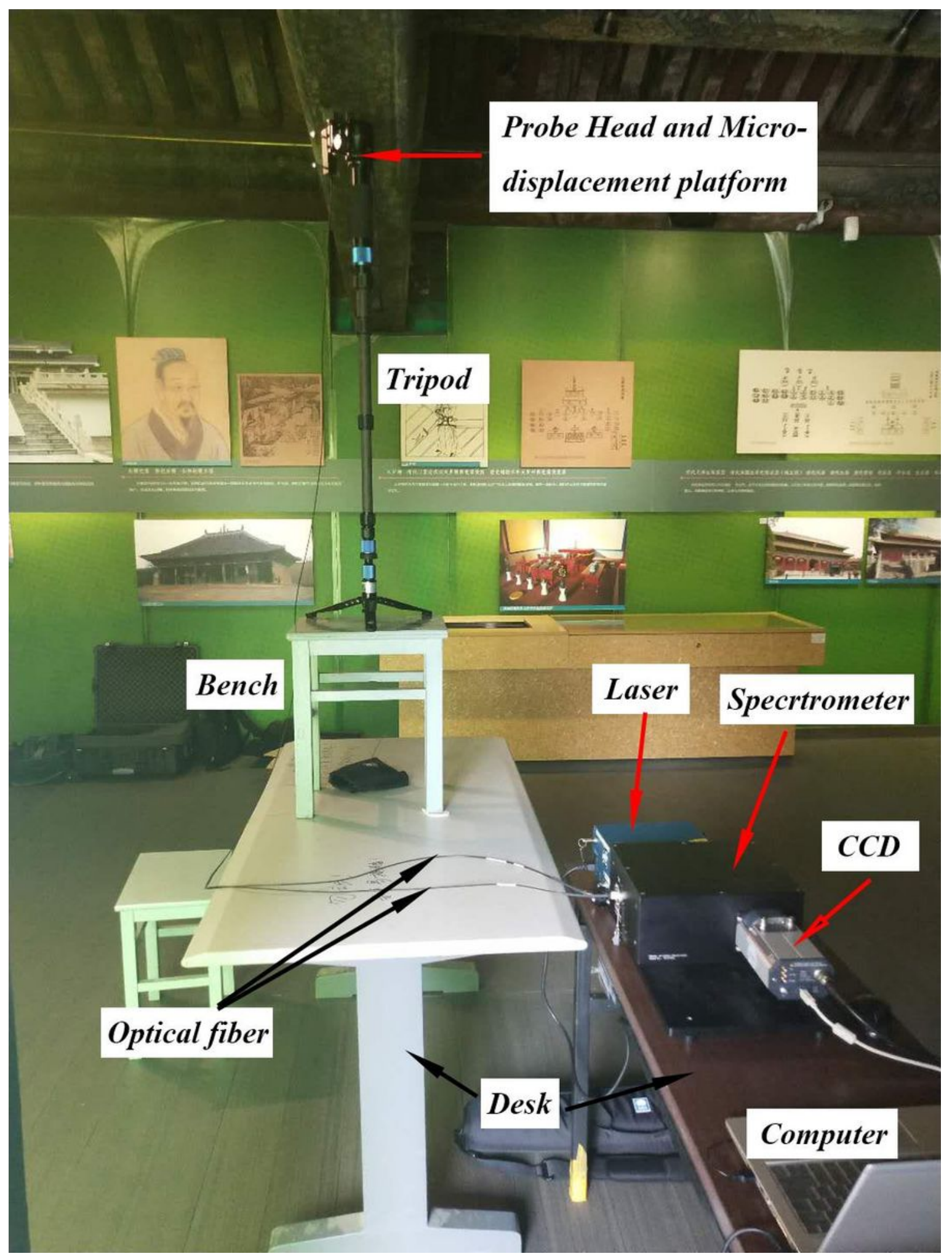

Figure 3

The photos of in-situ Raman measurement 

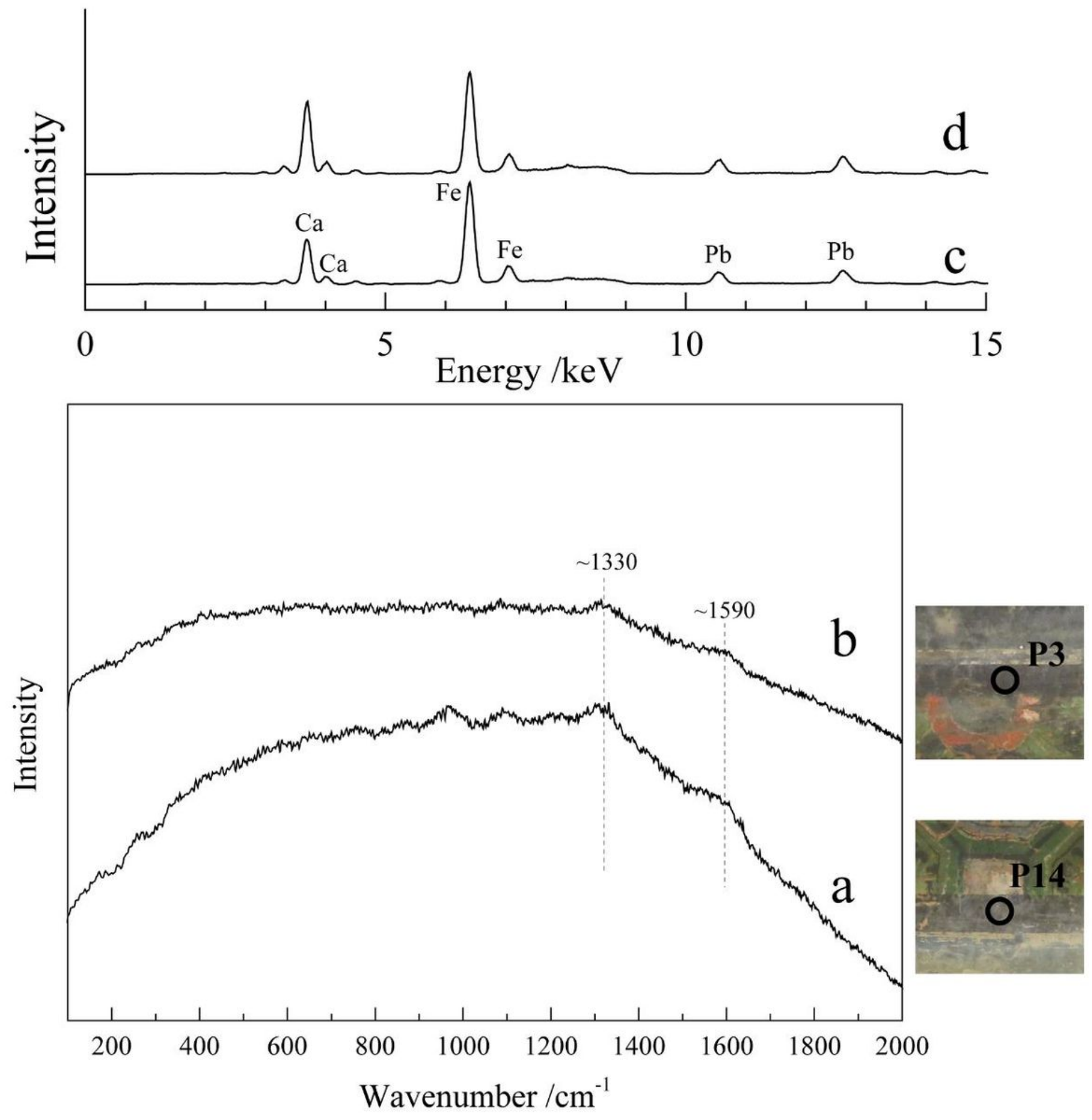

Figure 4

The Raman spectra and ED-XRF of the black area, a) P14, b) P3, c) ED-XRF of ground layer, d) ED-XRF of the black area 

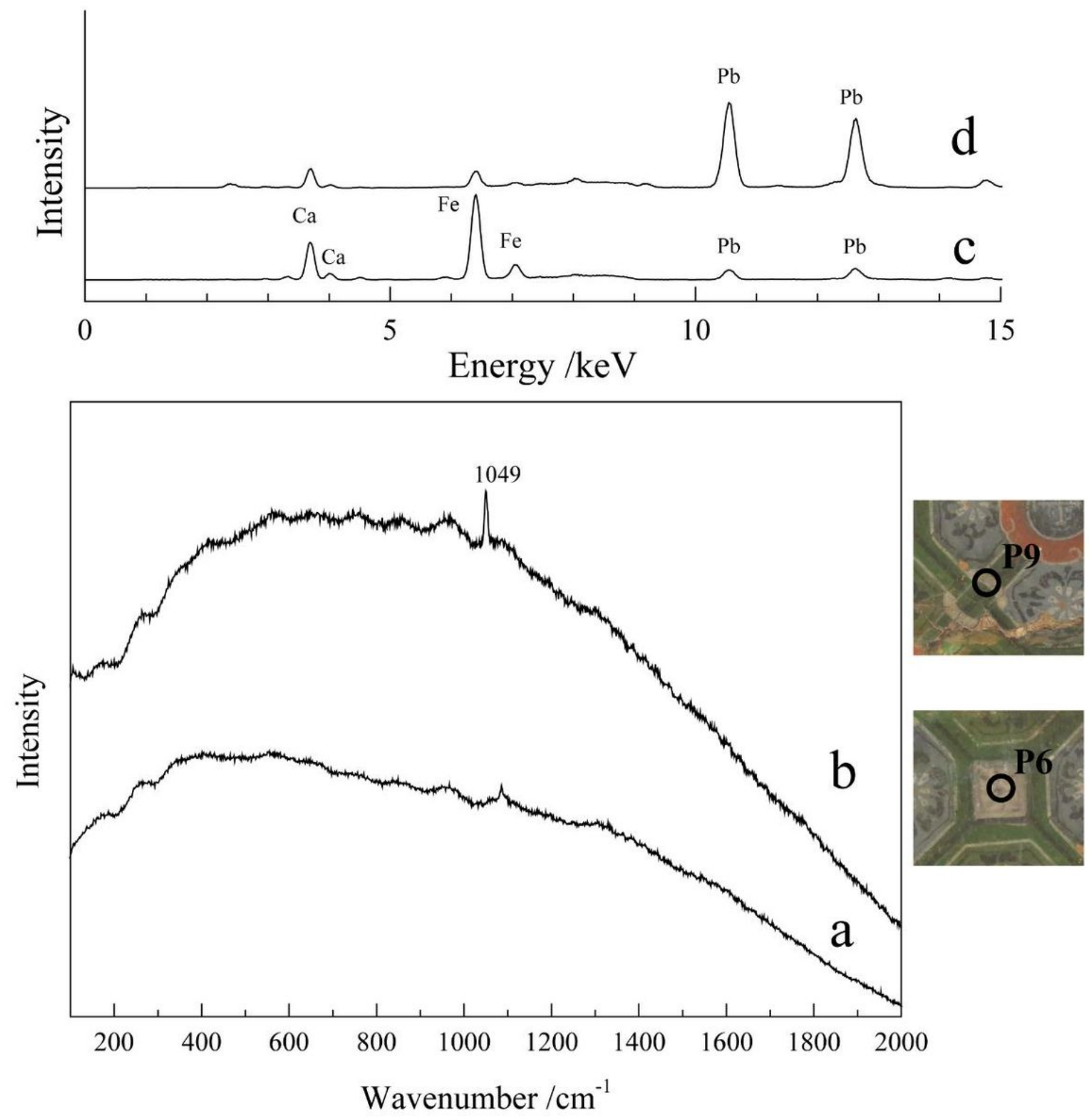

Figure 5

The Raman spectra and ED-XRF of the white area a) P6, b) P9, c) ED-XRF of ground layer, d) ED-XRF of the white layer 

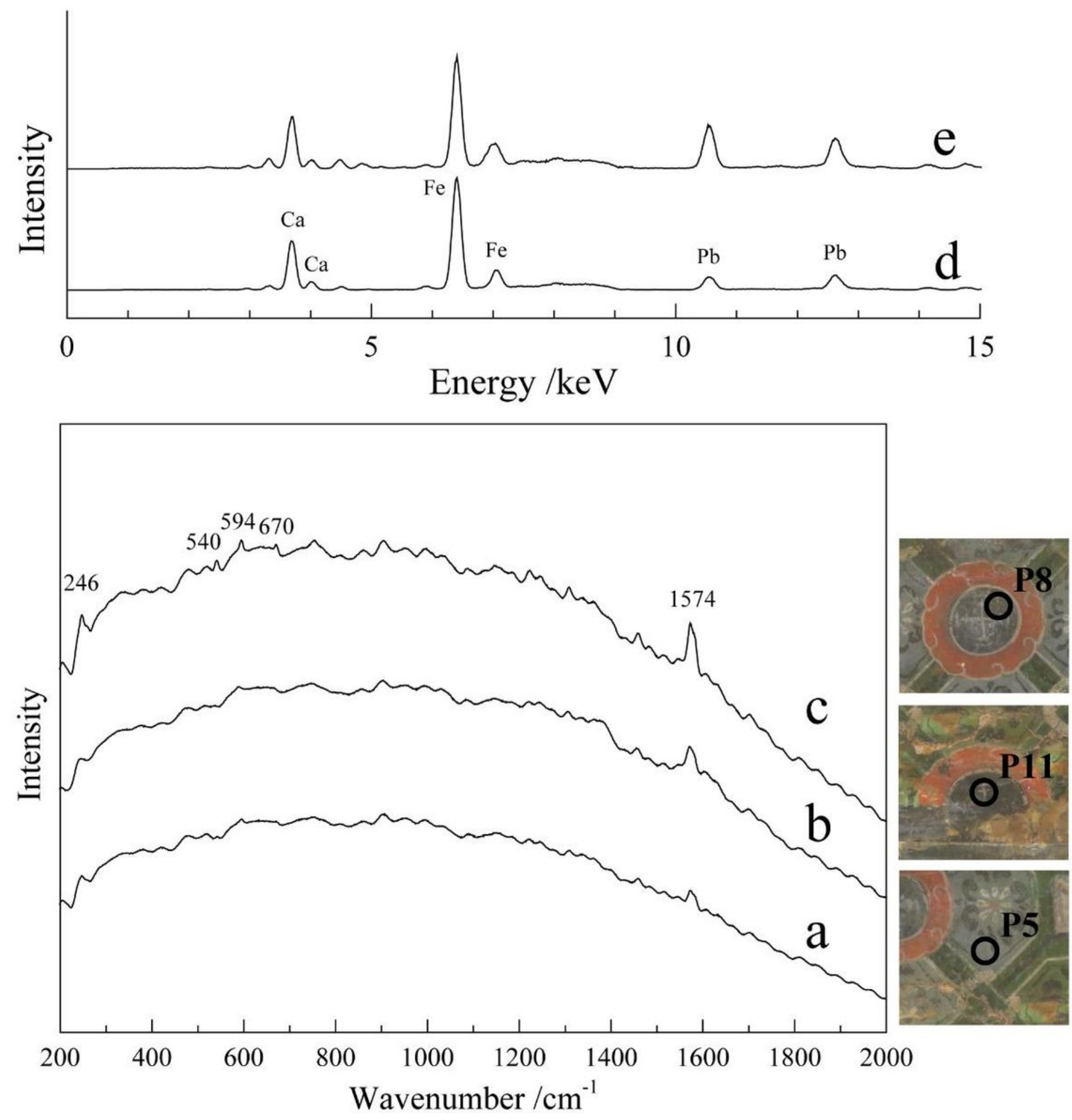

Figure 6

The Raman spectra and ED-XRF of the blue area, a) P5, b) P11, c) P8, d) ED-XRF of ground layer, e) EDXRF of the blue area 

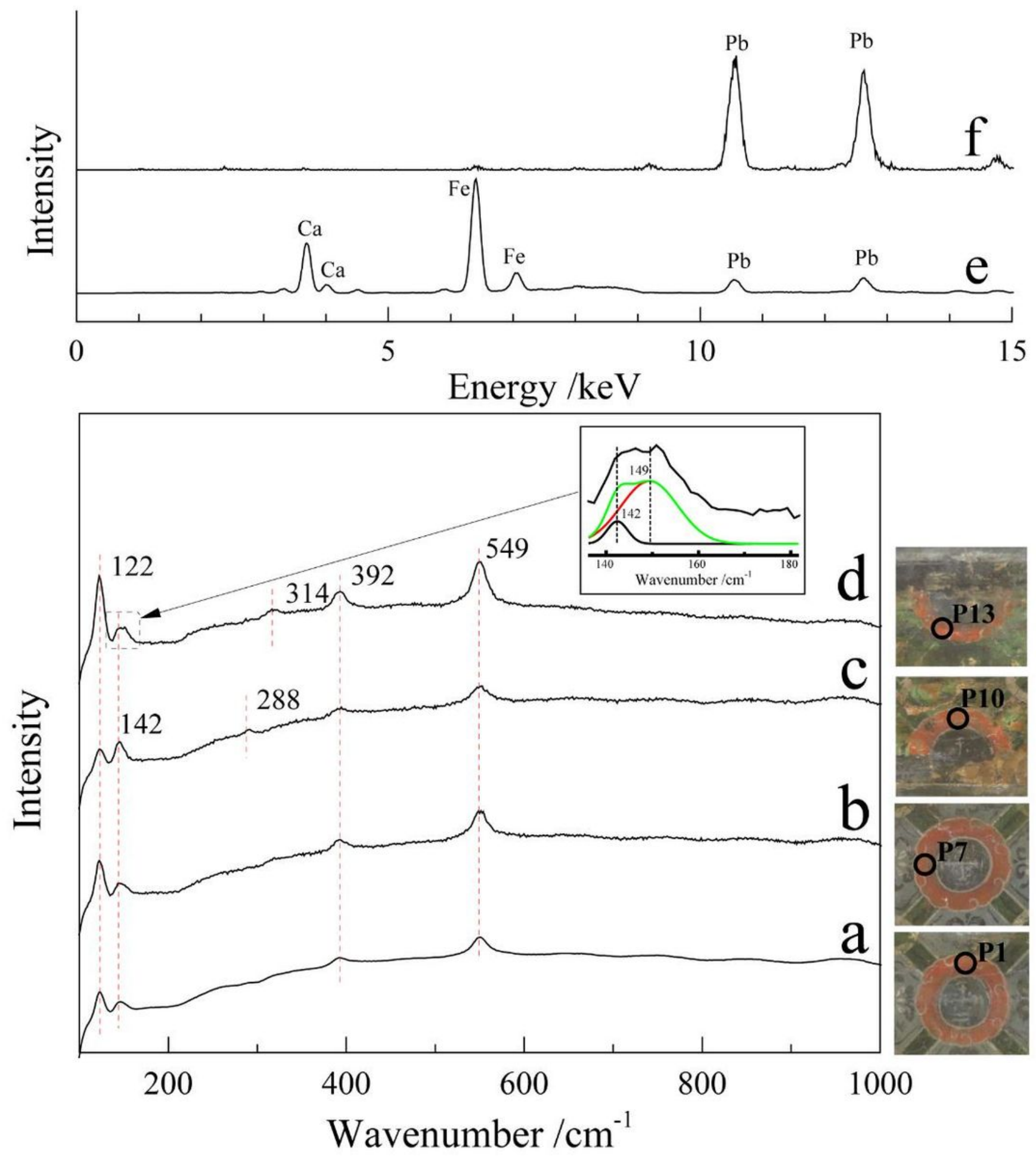

Figure 7

The Raman spectra and ED-XRF of the red areas, a) P1, b) P7, c) P10, d) P13, e) ED-XRF of the ground layer, $\mathrm{f}$ ) ED-XRF of the red area 


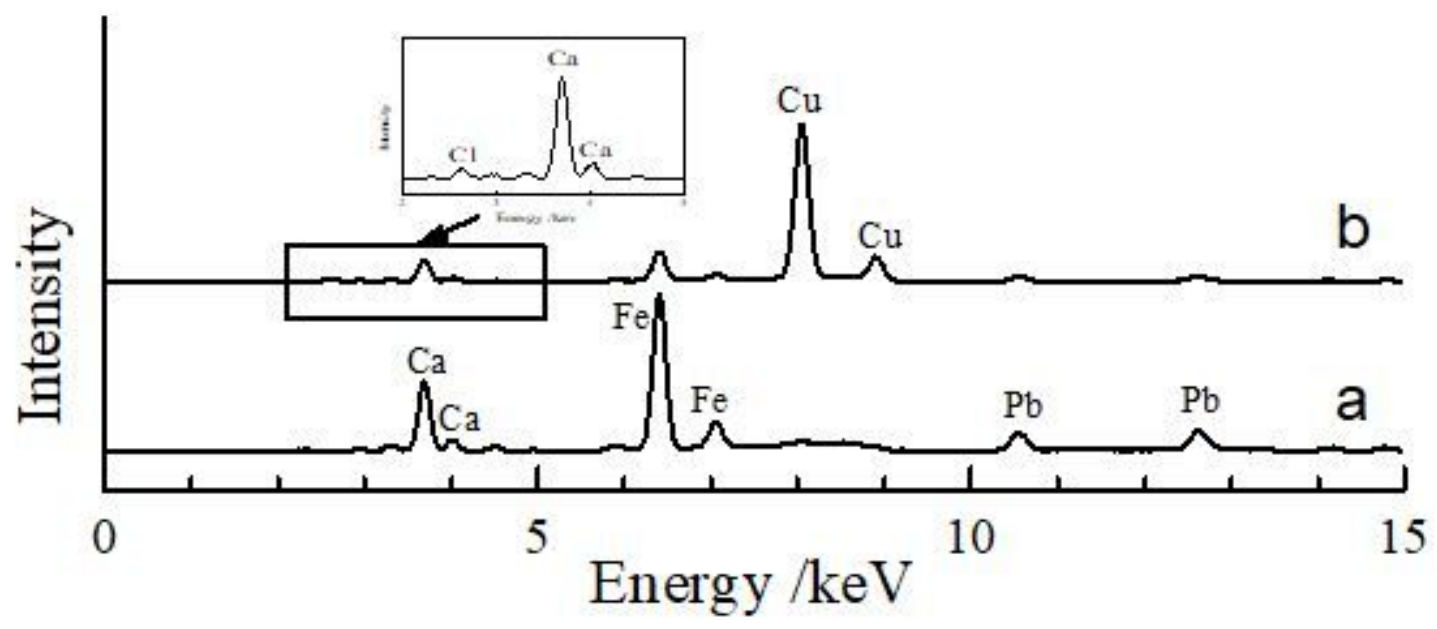

Figure 8

The ED-XRF of the ground layer (a) and the green areas (b)

\section{Supplementary Files}

This is a list of supplementary files associated with this preprint. Click to download.

- SupplementaryMaterial.docx 